\title{
Dhār, Bhoja and Sarasvatī: from Indology to Political
}

\section{Mythology and Back*}

\section{MICHAEL WILLIS}

The Bhojśālā or 'Hall of Bhoja' is a term used to describe the centre for Sanskrit studies associated with King Bhoja, the most celebrated ruler of the Paramāra dynasty. The Bhojśālā is also linked to Sarasvati - the goddess of learning - whose shrine is said to have stood in the hall's precinct. Since the early years of the twentieth century, the mosque adjacent to the tomb of Kamāl al-Dīn Chishtī in the town of Dhār has been identified as the Bhojśâlā. This has turned the building into a focal point of religious, social and political tension. Access to the site, currently under the protection of the Archaeological Survey of India, has been marked by communal friction and disputes in the press and in the courts. ${ }^{1}$ My aim in this paper is not to chart this sorry tale of events; I only need note that the legal and political wrangles, not to mention a steady flow of inflammatory assertions, have formed a toxic backdrop to the scholarly publications cited in the pages that follow. A second issue beyond the scope of this paper is how the medieval history of Dhār has played its part in the wider 'invention of tradition' and formation of modern Hindu identity. Stepping back from these concerns, my ambition here is rather modest: I seek only to explore how the mosque at Dhār has come to be described as the Bhojśāāa and, on this basis, to undertake an assessment of that identification. Along the way, I will touch on a number of problems concerning the history, architecture and literary culture of central India.

The starting point and centre-piece of the problem is King Bhoja, the ruler after whom the śâla has been named. He reigned between circa I000 and I055 and is generally represented as the greatest king of the Paramāra dynasty. ${ }^{2}$ Bhoja seems to have been an exceptional ruler by medieval standards and, unlike most rulers of the time, enjoyed a significant posthumous

*This article was prepared over a long period and I am grateful to many colleagues who helped in various ways. Hans T. Bakker, Paul Dundas, Whitney Cox and Dominik Wujastyk all took time to comment on the British Museum image inscription published below. I am especially grateful to Daniél Balogh for procuring a digital copy of S. K. Dikshit's edition of the Pärijätamañjari (cited below) without which it would have been impossible to complete this article. Thanks are also due to Dr O. P. Mishra who accompanied me on my first trip to Dhār in 2007 and offered many valuable insights as discoveries were being made. In London, I am grateful to Andrew Huxley and T. Phelps for comments on my text and for bibliographic information.

1 "Bid to Enter the Bhojshala", The Hindu (I9 February 2003); "Centre steps in to solve Bhojshala imbroglio", Times of India (I April 2003); both retrieved online in January, 20 I I.

${ }^{2}$ H. V. Trivedi, Inscriptions of the Paramāras, Chandellas and Kachchapapaghātas and two Minor Dynasties, Corpus Inscriptionum Indicarum, volume 7, 3 parts (New Delhi, I979-9I) I: 20 takes up the dates. Although his suggestion that Bhoja ascended the throne in circa Iooo has been generally accepted, the fact remains that the first dated inscription of Bhoja belongs to IOI I, ibid., 2: 29. The desire to have Bhoja's reign lasting 55 years is based on a wish to preserve the veracity of Merutunga's Prabandhacintämani (on which more below). The historiography of the problem is given in Mahesh Singh, Bhoja Paramāra and His Times (Delhi, I984), pp. 30-3 I. 
reputation. Tradition, beginning in about the twelfth century, has ascribed a large number of works on grammar, astronomy, yoga, architecture and other subjects to Bhoja, the most extensive in the field of poetics being the Śrngaraprakāsa. ${ }^{3}$ Whether Bhoja actually composed the works attributed to him is a theme taken up by several authors in this issue of the Journal of the Royal Asiatic Society. Here I only need add that the attribution of 84 texts to Bhoja is based solely on the assertion of Ājada, a western Indian author, in his opening remarks in the still-unpublished Sarasvatīkanțhābharanavrtti titled Padakaprakāsa ${ }^{4}$ Ājaḍa quotes Hemacandra (b. Io89) so he is coeval or after him in time. In addition to his literary interests, Bhoja began the temple at Bhojpur, a building with one of the largest Siva lingas in India. If completed, the temple would have been about twice the size of those at Khajurāho. There is no inscription at the temple itself, as we would expect in an unfinished structure, but there is a record in a neighbouring Jain temple that names Bhoja. ${ }^{5}$ Hitherto unnoticed in this regard is Merutunga's report that Bhoja bestowed on the poet Māgha "all the merit of the new Bhojasvāmin temple that he was about to build himself", and then "set out for the country of Mālava". ${ }^{6}$ This evidence, combined with the early eleventh-century style of the sculpture and architecture, leaves little doubt that Bhoja was indeed the king who founded the temple.

Bhoja's rising reputation after his death seems to have begun with his successor Arjunavarman (reg. circa I2 IO-I5) who stated that he was an actual reincarnation of Bhoja. ${ }^{7}$ Arjunavarman's claim coincides with the formalisation of Tibetan bLamas reincarnating in the Karma bka' brgud lineage, indicating the control of reincarnation was shared across several traditions. It was, of course, a useful mechanism for controlling religious endowments and political power. The practice originated in the eleventh century with standardised royal pedigrees that were seen to have a divine fountainhead. ${ }^{8}$ The idea of Bhoja reincarnating, figuratively at least, was perpetuated in Śvetāmbara Jain prabandhas, the oldest of which date to the first part of the thirteenth century. For example, the Prabandhakośa of Rājaśekhara, completed in I349, tells us that the poet Harihara made his way to Gujarāt and entered the court of Virradhavala, the Vaghela ruler. ${ }^{9}$ Coming before the king's famous minister Vastupāla

\footnotetext{
${ }^{3}$ Venkatarama Raghavan, Bhoja's Śrngaraprakāśa, 3rd rev. ed. (Madras, I940). The text is taken up by Whitney Cox in this $J R A S$ issue.

${ }^{4}$ See C. Kunhan Raja, V. Raghavan et al, New Catalogus Catalogorum, I4 vols. (Chennai, I949-200o) 2, p. 240 (hereinafter NCC) and L. B. Gandhi, A Descriptive Catalogue of Manuscripts in the Jain Bhandars at Pattan, Gaekawad Oriental Series, no. 76 (Baroda, I937), pp. 37-39 and introduction, p. 48; Sanskrit introduction, p. I2.

${ }^{5}$ See D. C. Sircar, “Three Paramara Inscriptions", Epigraphica Indica 35 (1963-64), p. I86; Trivedi, Inscriptions of the Paramāras, 2, pp. 60-6I.

${ }^{6}$ See C. H. Tawney, The Prabandhacintāmani or Wishing-stone of Narratives (Calcutta, I90i), pp. 48-49. Māgha was earlier than Bhoja but placing poets of different periods in Bhoja's court is a feature of the prabandha genre.

${ }^{7}$ See S. K. Dikshit, (ed.), Pārijātamañjarī alias Vijayásín by Rāja-Guru Madana alias Bāla-Sarasvatī (Bhopal, I968), Introduction, p. x. The framework of poetic biographies and the title Bālasarasvatī is explored in Phyllis Granoff, "Sarasvatî’s Sons: Biographies of Poets in Medieval India," Asiatische Studien / Études Asiatiques 49.2 (I995), pp. $35 \mathrm{I}-376$. Further examples can be noted: one Bālasarasvatī was named Krṣna and was the grandson of the author of the Kuvalayāsvacārita, see A. S. Gadre, G. Yazdani and R. G. Gyani (eds), Important Inscriptions from the Baroda State, 2 vols. (Baroda, I943-44), I, p. 84 (v. 36): kavih kuvalayā́sacāitradhātuh kṛnnah praśastim iha ratnasutah sa tene. Another Bālasarasvatī was named Ājaḍa. He was son of another Ājaḍa, author of the Vivekamañjari of CE I I93, see NCC 2 , p. 240. Both are different from the Ājada mentioned above (see note 4), the author of the Sarasvatikanthäbharanavrtti.

${ }^{8}$ See Hans T. Bakker, "Throne and Temple: Political Power and Religious Prestige in Vidarbha”, in The Sacred Centre as the Focus of Political Interest, (ed.) Hans T. Bakker (Groningen, I992), pp. 83-100.

9 Jina Vijaya Muni, (ed.), Prabandhakośa of Rājaśekhara (Śāntiniketan, I935), the portions here drawn from Phyllis Granoff, "Sarasvatî’s Sons", p. 356.
} 
he is reported to have said: "My lord! You are like a reincarnation of the great king Bhoja in your patronage of the arts! You are like the God Brahmā in your ability to discern the truth and you are a jewel on the neck of the goddess Sarasvatī in your refined poetic sensibilities!"

The most extensive account of Bhoja's character and ambitions in the prabandha-genre is Merutunga's Prabandhacintamani, completed in the opening years of the fourteenth century. ${ }^{10}$ Post-medieval collections, such as Ballāla's Bhojaprabandha, composed at Benares in the seventeenth century, continued to extol Bhoja's greatness. ${ }^{11}$ This tradition was picked up in the twentieth century as India searched for indigenous cultural heroes. In the words of K. K. Munshi, “... during Bhoja’s rule civilization in Mālwā had risen to a magnificent pitch. Our appreciation of Bhoja for having portrayed a faithful picture of the most glorious period of medieval Indian History [in the Śrngāramañjarikathā] is heightened when we take into consideration that he worked and stood for all that was glorious in Hindu Culture". ${ }^{12}$ These words make somewhat curious reading to contemporary eyes but they are given a degree of context by Frederic Morell Holmes, Four Heroes of India (London, I 892) where we find, to our general astonishment, that India's four heroes are Clive, Hastings, Havelock and Lawrence! As a consequence of all this, sites and objects connected with Bhoja have acquired cultural potency and are intimately connected with modern Hindu identity in central India. ${ }^{13}$ And few places have come to have more potency in this regard than the Bhojśālā at Dhār.

\section{Dhār and its monuments}

Given the Bhojśâlā has become the scene of a fraught communal drama, it is not inappropriate to 'set the stage' with an account of Dhār and its monuments. As we will see in the pages that follow, many of the popular assertions about the Bhojsāāa can be attributed to a misunderstanding of the wider literary, historical and urban context of the building. The old town of Dhār is of considerable antiquity, the first reference to it appearing in the Jaunpur inscription of the Maukhari dynasty. ${ }^{14}$ Already in this record there is a play on the word 'sword' or dhārā, showing that the prevailing etymology of Dhārānagara as the 'city of sword blades' was current from at least the sixth century. The consistency of the usage, with no further synonyms as far as I am aware, might indicate that swords were once manufactured at Dhār, but it seems more probable that the name shows the city was a recurrent scene of conflict because it was an essential stronghold for any king aspiring to control central India. ${ }^{15}$

\footnotetext{
${ }^{10}$ Jina Vijaya Muni, (ed.), Prabandhacintāmaṇi of Merutungāaārya (Śāntiniketan, I933), translated as Tawney, Prabandhacintämani. The rhetorical strategies of Merutunga, essential for understanding his use of history, are explained in Toshikazu Arai, "Jaina Kingship in the Prabandhacintāmaṇi", in Kingship and Authority in South Asia, (ed.) J. F. Richards (Madison, I978, reprint., Delhi, I981), pp. 92-I32.

${ }^{11}$ Louis H. Gray, The Narrative of Bhoja (Bhojaprabandha), American Oriental Series, vol. 34 (New Haven, I950).

${ }^{12}$ K. K. Munshi, (ed.) Śrngāaramañjarīkathā, Singhī Jaina granthamālā, no. 30 (Bombay, I959), p. 90.

${ }^{13}$ See, for example, Bhoj Shala - Ek Sangharsa Gatha, which can be seen on Youtube (retrieved January, 20II). The majority of people who identify themselves as Hindu do not, of course, endorse these strident views.

${ }^{14} \mathrm{~J}$. F. Fleet, Inscriptions of the Early Gupta Kings and their Successors, Corpus Inscriptionum Indicarum, vol. 3 (Calcutta, I 888), p. 228 (line 6). Hans T. Bakker, “The So-Called Jaunpur Inscription of İ́saravarman" Indo-Iran Journal 50 (2009), pp. 207-216, shows that the inscription belongs not to İ́saravarman but to İsānavarman or one of his successors.

${ }^{15}$ In this issue of the $J R A S$ Csaba Dezső's article has insightfully highlighted the symbolism of swords in Dhanapāla's Tilakamañjarī.
} 


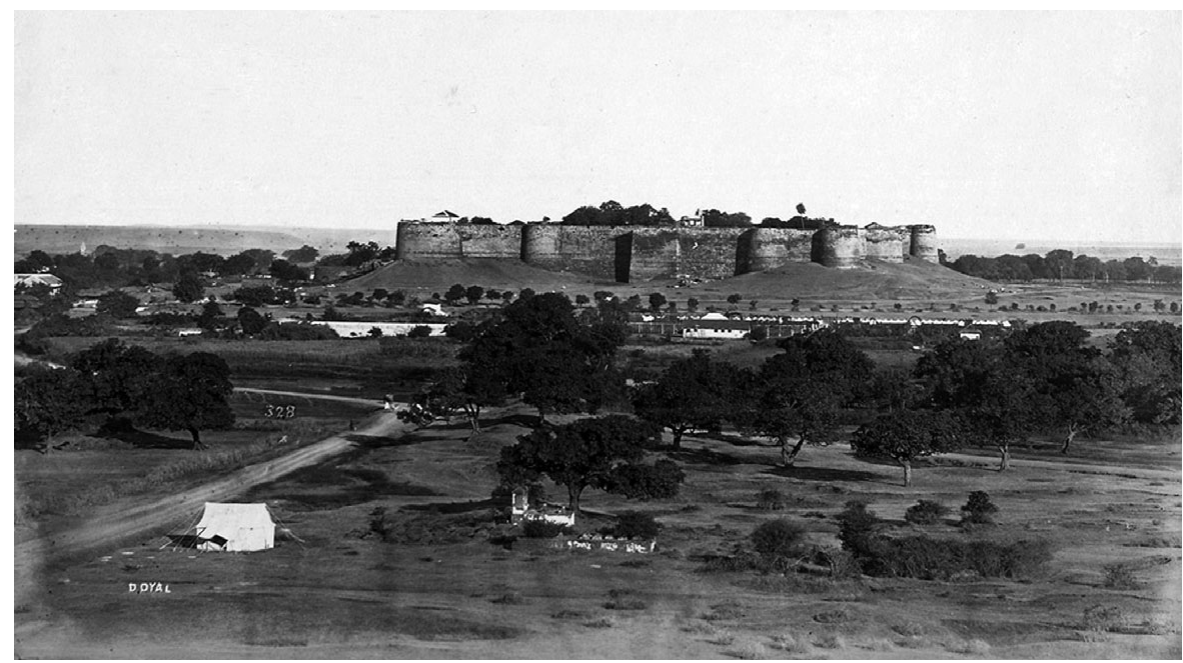

Fig. I. Dhār fort. General view. Photograph by Deen Dayal, i 882. Courtesy of the British Library, Photo 2/4(90), item 90.

The town of Dhār is dominated by a large stone fortress (Fig. I). Although partly surrounded nowadays by the modern town, the fort remains an imposing structure. The date of its construction is not documented by inscription, but Jahāngīr visited the place in I6I 7 and referred to it in his memoirs, stating that “... when Sultan Muhammad ibn Tughluq was proceeding to the conquest of the Deccan, he built a fort of cut stone on the top of the ridge. Outside it is very showy and handsome, but inside the fort is devoid of buildings". ${ }^{16}$ One of the gateways, added at a later time, is dated I $684-85$ in the reign of ${ }^{c} \bar{A}$ lamgir. ${ }^{17}$ Inside the fort there is a deep rock-cut cistern, probably of great age and around which the pre-Tughluq fort was probably built. ${ }^{18}$ A later palace on one of the bastions, the Kharbhuja Mahal, incorporates an elegant pillared porch and appears to belong to the same period as the seventeenth-century gate. A few low buildings in a functional style were added in British times.

Jahāngīr's attribution of the fort to Muhammad ibn Tughluq (I325-5I) is confirmed by the general similarity of the fortifications to those at Tugluqābād in Delhi. ${ }^{19}$ The attribution is also supported by the policies of the Tughluqs who sought to consolidate their control over the territories conquered by the Khaljīs. Muhammad ibn Tughluq signalled his wish to exercise power over the southern parts of his dominion by making Daulatābād the imperial

\footnotetext{
${ }^{16}$ Francis Gladwin, The History of Jahangir, (ed.) with notes by Rao Bahadur K. V. Rangaswami Aiyangar (Madras, I930), p. I73; The Tūzūk-i-Jahāngìri or Memoirs of Jahāngìr, translated by Alexander Rogers and edited by Henry Beveridge, 2 vols. (London, I909) 2, p. 407, cited with a slightly different translation of the passage in CE Luard, Dhar \& Mandu: A Sketch for the Sight-seer (Bombay, I9I6), p. 8.

${ }^{17}$ Annual Report on Indian Epigraphy (I97I-72), p. 8I, no. D. 72 (hereinafter cited as ARE). The inscription is reported on a metal plaque on the wooden gate and although local people knew of it, I was unable to locate the plaque when visiting the site.

${ }^{18}$ Suggested by K. K. Lele, in Dikshit, Pārijātamañjarī, p. xxi, n. I, who identifies it, correctly I think, as the Dhārāgiri mentioned in the play.

${ }^{19}$ Mehrdad Shokoohy and Natalie H. Shokoohy, Tughluqabad: A Paradigm for Indo-Islamic Urban Planning and Its Architectural Components (London, 2007).
} 


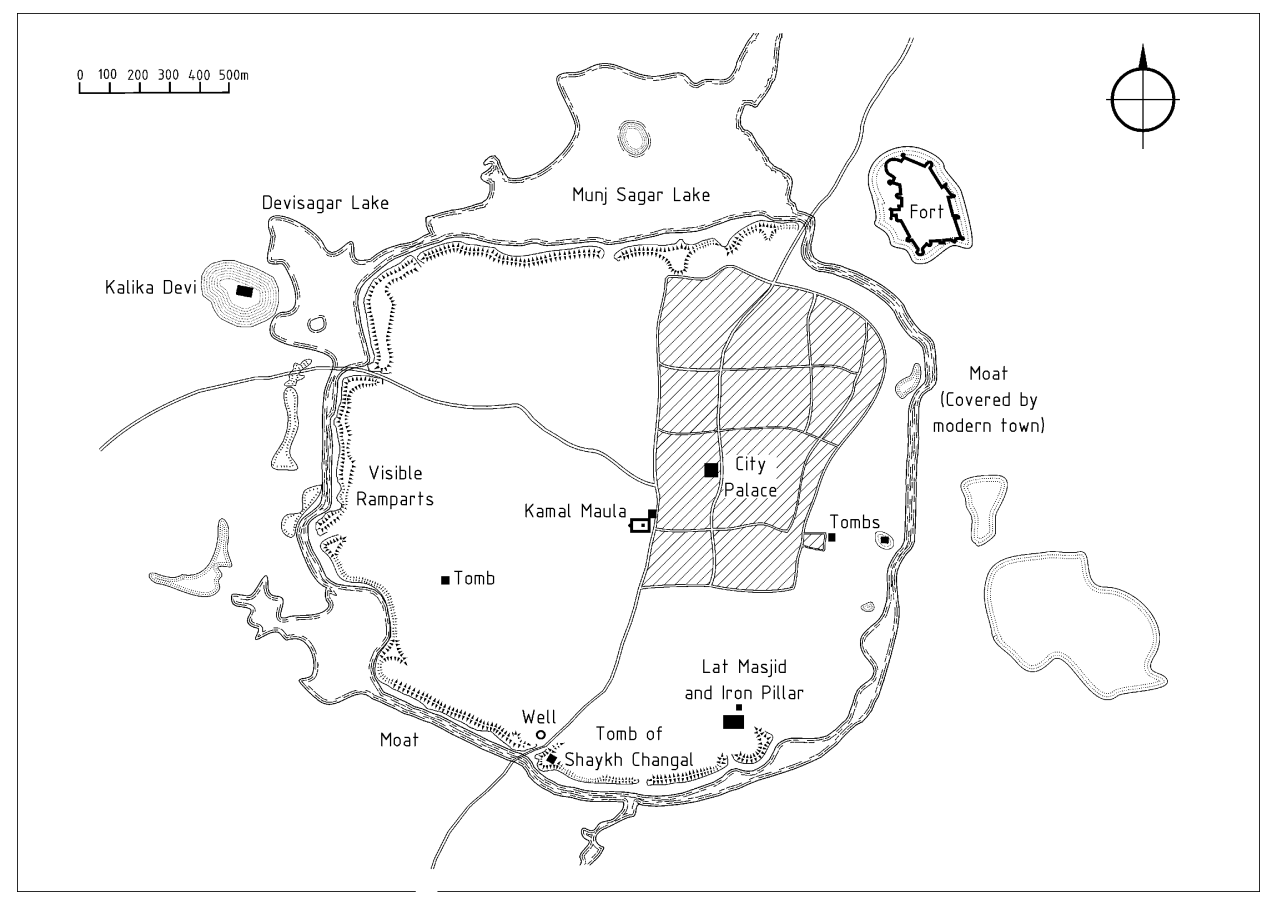

Fig. 2. Dhār. Plan of the medieval town showing the location of monuments and disposition of the ramparts.

co-capital in I $337 .{ }^{20}$ That Dhār was a key staging-post on the road to the Deccan is shown by the fact that when 'Ala' al-Dīn Khiljī dispatched ${ }^{\mathrm{c}}$ Ayn al-Mulk Mūltānī to subdue Mālwa in the early fourteenth century, the latter made Dhār the provincial capital and served there as governor until I3 I 3 after which time he was transferred to Daulatābād. ${ }^{21}$ It was still the capital of Mālwa some years later when Ibn Battūṭa travelled to the Deccan. ${ }^{22}$

The fort at Dhār stands on the north-eastern edge of a circle of tanks, channels and earthen ramparts that made Dhār, in effect, a moated, circular city (Fig. 2). This plan is alluded to in Merutunga's Prabandhacintāmani and is similar to that at Warangal in the Deccan. ${ }^{23}$ As the circular configuration is probably mentioned by Padmagupta in his Navasāhasāinkacarita, a work that casts King Bhoja's father Sindhurāja as a latter-day Vikramāditya, it seems likely that the plan was already taking shape in the tenth century. ${ }^{24}$

${ }^{20}$ Richard Eaton, A Social History of the Deccan, 1300-1761: Eight Indian Lives (Cambridge, 2005), p. 38.

${ }^{21}$ Iqtidar Husain Siddiqui, Authority and Kingship under the Sultans of Delhi (Delhi, 2006), pp. 283-284.

${ }^{22}$ H. Yule, "The Geography of Ibn Battuta's Travels in India”, Indian Antiquary 3 (I874), p. I I6.

${ }^{23}$ George Michell, "City as Cosmogram: The Circular Plan of Warangal", South Asian Studies 8 (I992), pp. I-I8. Tawney, Prabandhacintämaṇi, p. 46 where the plan is said to have been based on Lanka (i.e. an island) and laid out according to the designs of Dhārā, a courtesan. A detailed study of the circular city, first noted in 2007 by Dr O. P. Mishra and myself, is reserved for a future time; the drawing published here is accurate but only preliminary.

${ }^{24}$ Padmagupta, Navasāhasāinkacarita with Hindī commentary, introduction etc., by Shastrī Jitendrachandra Bhāratìya (Varanasi, I963). A translation is awaited; for the moment readers may refer to the relevant sections in A. K. Warder, Indian Kāvya Literature, 7 vols (Delhi, 1972-2004). 


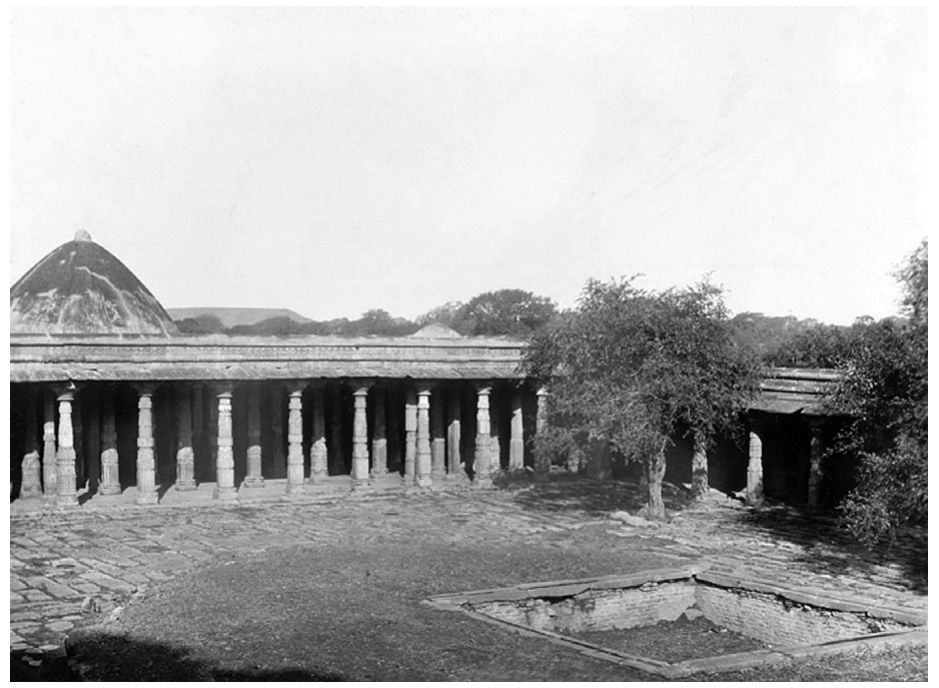

Fig. 3. Dhār. Interior of the Mosque at the tomb of Kamāl al-Dīn. Unknown photographer, I902. Courtesy of the British Library, Photo 2/4(90), item 43032 I 2.

In the exact centre of the circular city is the tomb of Kamāl al-Dīn Mālawī (circa I238I330). This Chishtī saint, called Mālawī because of his long residence in central India, was a follower of Farīd al-Dīn Mas ${ }^{\mathrm{u}} \mathrm{d}$ Ganj-i Shakar (I I75-I265) and Nizāàm al-Dīn Auliyā' of Delhi (circa I243/4-I325). Some details about Kamāl al-Dīn are recorded in Muhammad Ghawthī's Gulzār-i abrār, a reliable hagiography of Sufi saints composed in I6r $3 .{ }^{25}$ The custodians of Kamāl al-Dīn's tomb have served in an unbroken lineage for almost seven hundred years and are still resident; their history can be found in an informative volume by Rām Sevak Garg. ${ }^{26}$ The structures in the complex belong primarily to the fifteenth century as documented by inscriptions still in situ. ${ }^{27}$

Next to the tomb is a spacious hypostyle mosque built primarily of reused temple parts (Fig. 3). When this building was constructed is not recorded, but an inscription of AH 795/1392-93, dug up in the small graveyard of the adjacent enclosure, mentions that the mosques of Dhār had fallen into disrepair and that they were renewed by Dilāwar Khān. ${ }^{28}$ This suggests that the mosque next to Kamāl al-Dīn's tomb was the first Jāmic , constructed soon after Dhār was annexed to Delhi and made headquarters of the province under ${ }^{\mathrm{c}}$ Ayn al-Mulk Mūltānī. As noted above, Mūltānī served as governor until I 3 I 3 so it seems likely that the mosque was completed prior to his departure. Some seventy years later, in $\mathrm{AH}$

${ }^{25}$ Muhammad Ghawthī Mandawi, Azkar-i abrār, Urdu Tarjuma-i Gulzār-i abrār, trans. Fazl Ahmad Jewari [Urdu lithograph] (Agra, I326/I908, reprint ed., Lahore: Islamic Book Foundation, I395/I975), p. 58I. I am grateful to Richard Eaton for drawing this source to my attention. The text is available in digital form through http://www.archive.org

${ }^{26}$ Rām Sevak Garg, Hazrat maulānā kamāluddīn ciśtì rah. aur unkā yug (Bhopāl, 2005).

${ }^{27}$ G. H. Yazdani, Epigraphia Indo-Moslemica (I909-Io), p. I4, pl. V (hereinafter cited as EIM); ARE (I97I-72): 8I, no. D. 76.

${ }^{28}$ Zafar Hasan, "The Inscriptions of Dhar and Mandu," EIM (I909-Io), pp. I3-I4, pl. II, no. 2; ARE (I97I72): $8 \mathrm{I}$, no. D. 73. The discovery of the inscription, shortly after I902, is recorded in Ernest Barnes, "Art. XI. Dhar and Mandu," JRAS Bombay Branch 2 I (I903), p. 349, n. I. 
793/I390-9I, Sultān Muḥammad Shāh appointed Dilāwar Khān muqtic of Dhār (and thus governor of Mālwa), so the renovations of ${ }^{1392-93}$ can be seen as inaugurating Dilāwar Khān's governorship. ${ }^{29}$

The variety of pillars used in the building, and the number of inscribed tablets still visible in the floor with yet others displayed along the walls, show that the materials for this building were collected from a number of old sites over a wide area. The approach to the construction of the mosque deliberately mimics what was done at the Qutb in Delhi. Both buildings do not simply use temple material because nothing else was available or because the use of temple pillars was a triumphant display of Islamic supremacy. Rather, the reuse of old temple parts represented a comprehensive appropriation of the resources of the past both architectural and cultural - and their radical reconfiguration into a new kind of sacred space unknown in India before the appearance of Islam. Just as individuals could choose to become Muslim and find a place in the new Islamic dispensation, so too pillars, beams and slabs could be converted and find an appropriate role the new architecture. In British India there was little interest in exploring or explaining these cultural practices, as we will see in the pages that follow.

The mosque at Kamāl al-Dīn was displaced as the focus of Friday prayers when Dilāwar Khān, assuming the title ${ }^{c}$ Amīd Shāh Dāwūd Ghōrī, built what is called the Lāt masjid as the new Jāmic in ${ }^{c} 405 .{ }^{30}$ The Làt masjid derives its name from the pillar or lăt lying outside the building. Being a monolith cast in iron, the pillar is a technological marvel that has drawn considerable attention through the centuries. ${ }^{31}$ Jahāngīr reports that Dilāwar Khān installed the pillar outside the building. ${ }^{32}$ Where it was before Dilāwar Khān's time has not been discussed in a definitive fashion. Here I would note that because the old Jāmic at Kamāl al-Dīn was modelled on Delhi, it seems likely that the pillar at Dhār played an analogous role to the iron pillar at the Qutb and so stood at Kamāl al-Dīn between circa I 305 (conquest of Dhār and building of the first Jāmic) and circa I405 (declaration of independence by Dilāwar Khān and the building of the second Jāmic ${ }^{c}$. The location before circa I 305 remains uncertain. Originally some $13.5 \mathrm{~m}$ in length, the pillar was broken when the Sultan of Gujarāt attempted to move it in the I 50os. The three surviving portions are now placed on a small platform outside the Lât mosque. ${ }^{33}$ The only dated inscription on the pillar records a visit by the Mughal Emperor Akbar in I 598 while on campaign towards the Deccan. ${ }^{34}$

The Lāt masjid is situated at the south-eastern edge of the old town near to what would have been the gate to Māṇ̣ū. Because Māṇ̣ū had long served as a hill-retreat for those at Dhār, it was natural for Dilāwar Khān to have built the new Jāmic on this side of the town. A similar pattern is seen at other centres, notably Chanderi, where a new Jāmic was constructed on the western edge of the town in the same period. ${ }^{35}$ A key feature of the Lât

\footnotetext{
${ }^{29}$ For date of Dilāwar Khān's appointment, U. N. Day, Medieval Malwa (Delhi, I969), p. I3.

${ }^{30}$ Zafar Hasan, EIM (I909-Io), pp. I2-I3; ARE (I97I-72): 8I, no. D. 73.

${ }^{31}$ A full bibliography can be found in R. Balasubramaniam, "A New Study of the Dhar Iron Pillar," Indian Journal of the History of Science 37.2 (2002), pp. I I 5-I 5 I.

${ }^{32}$ Tüzük-i Jahāngìiri, 2, p. 407.

${ }^{33}$ The old photograph in Luard, Dhar \& Mandu, (with another in Balasubramaniam, "A New Study") shows the fallen pillar beside the stone footing, prior to it being set on a platform by the Archaeological Survey of India in about 1980 .

${ }^{34}$ Zafar Hasan, EIM (I909-10), p. I3; translation in Barnes, "Dhar and Mandu", p. 348.

${ }^{35}$ Gérard Fussman et al, Naissance et déclin d'une qasba: Chanderi du Xe au XVIII siècle (Paris, 2003).
} 
masjid is the reduced number of re-used temple pillars compared to the mosque at Kamāl al-Dinn, and the corresponding reduction in the depth of the prayer-hall colonnades. This indicates that there were substantially fewer pillars available for the construction. In addition to these well-known monuments, there are a number of other tombs of the fifteenth and sixteenth century at Dhār that have received little scholarly attention; an account of these buildings, important as they are, is outside the scope of the present essay. ${ }^{36}$

\section{Dhār and the 'discovery' of the Bhojśālā}

Dhār and Mānḍū were known to be important places in the nineteenth century and their histories began to be explored at an early date. Although the oldest writing is not as revealing as we would like, a review of the literature nonetheless shows how the tradition of the Bhojśālā began to emerge.

The first account of Dhār in a western language is found in John Malcolm's Report on the Province of Malwa. That was published in I 822. ${ }^{37}$ Malcolm's treatment of Dhār is brief, but in his historical survey he notes that it became the capital under Bhoja in the eleventh century. In a footnote Malcolm gives an extended account of one of the folk-tales that were current in his time. According to one story, Bhoja made a vow to build a series of dams "to arrest the streams of nine rivers and ninety-nine rivulets". ${ }^{38}$ A location was found in the kingdom that allowed the king to fulfil this vow and the dams were duly built at the site we now call Bhojpur. The dam at Bhopāl, according to this story, was built by the king's minister. In his description of Dhār, Malcolm is very brief, saying only that: "The materials of its finest temples appear to have been appropriated to build Palaces and Mosques for its new sovereign. The city did not however, remain the capital of the Mahomedans for long. Alif Khan (the son of Dilawur Khan) who became celebrated under the name of Hoshung Sha, removed the seat of Government to Mandoo". In a footnote he adds: "I took, when last at Dhar, a fine polished stone tablet of large dimensions, on which there was a Hindu Inscription, from a ruined Mosque, where this sacred writing had been placed as the floor of the Mimbur or pulpit of the Mahomedan place of worship" ${ }^{39}$ This is the first reference to the mosque of Kamāl al-Dīn and to the numerous inscribed slabs that subsequent visitors repeatedly observed in the floor of the building. Aside from the obvious fact that Malcolm makes no reference to the Bhojsāalā, and clearly describes the building as a ruined mosque, what draws our attention is the inscribed slab he extracted from the minbar. This has not, so far as I am aware, been noted or traced; there is a tantalising possibility that his "fine polished stone tablet" is the missing part of the inscription containing the drama Pärijätamañjari composed by Madana, the preceptor of the Paramāra King Arjunavarman, on which more below.

The encyclopaedic care with which Malcolm prepared his report made his book a standard reference and led to its republication in several editions under the title A Memoir of Central India, including Malwa and Adjoining Provinces. The only other work in circulation was William

\footnotetext{
${ }^{36}$ The only account is given in Barnes, "Dhar and Mandu", p. 353; also see the article by R. Babagolzadeh in this issue of the JRAS.

${ }^{37}$ John Malcolm, Report on the Province of Malwa, and adjoining Districts (Calcutta, I 822).

${ }^{38}$ Ibid., p. I9.

${ }^{39}$ Ibid., p. 2 I.
} 
Kincaid's I 879 edition of the History of Mandu, first published in I $844 .{ }^{40}$ Kincaid spent most of his life in Mālwa and recorded a number of folk-tales about Bhoja in the I 888 volume of Indian Antiquary. ${ }^{41}$ Like Malcolm, he documents popular memories of Bhoja as a great king, with a similar account of the temple and dams at Bhojpur. The Bhojs̄âlā is singularly absent in these stories. In his detailed notes on Dhār and Mānḍ̂u, added as numbered appendices to the History of Mandu, Kincaid mentions the Akl ka kua or 'Well of Wisdom' in front of the tomb of Kamāl al-Dīn, observing, in passing, that "a loquacious Musalman here recounted to me a number of remarkable stories". ${ }^{42}$ Of the mosque, however, he only says “. . . close by is a small masjid". While Kincaid was not the most sympathetic of ethnographers, if there had been an active folk-tale about the Bhojsāāā, the talkative person he encountered would surely have mentioned it and Kincaid made a note. The silence of both Malcolm and Kincaid on this point shows that there were no living traditions about the Bhojśâlā in the middle decades of the nineteenth century.

The degree to which the Memoir of Central India and the History of Mandu held sway is shown by Guiaud's Ruins of Mandoo. Guiaud acknowledged that his historical notices were culled "chiefly from the pages of Sir John Malcolm's History of Central India, and from a small work published at Bombay in I 844 , by A Bombay Subaltern". ${ }^{43}$ Guiaud, as a consequence, adds nothing to our understanding of Dhār and the problems we seek to address in this essay.

Epigraphic research at Dhār began in earnest in I 87I when Bhau Dāji of Bombay sent his agents to take copies of inscriptions at Dhār. ${ }^{44}$ Dāji died in I 874 and does not seem to have done anything with these copies in the final years of his life. Nonetheless, Dāji did have an active interest in the literary figures at Bhoja's court and the prabandhas attached to Bhoja's name. ${ }^{45}$ Of Dhār itself, however, he says nothing.

After Dāji, epigraphic research at Dhār was continued by Georg Bühler in I 875 , or at least so we are told by C. E. Luard in his Gazetteer of $1908 .{ }^{46}$ However, Bühler's presence in Dhār is not something I have been able to trace. Bühler's report for I $874-75$ documents a trip through Rājasthān in search of manuscripts; his report for $1873-74$ also focuses on Rājasthān. ${ }^{47}$ Indeed in his report for I $873^{-74}$ he notes: "In conclusion, I beg to express the hope that Government will be pleased to give me an opportunity and funds to continue the

${ }^{40}$ History of Mandu, The Capital of Malwa. By a Bombay Subaltern, (ed.) by William Kincaid, $2^{\text {nd }}$ ed. (Bombay, I 879). The notes at the end are by Kincaid (I83 I-I909) who served in a number of roles, notably as Resident in Bhopawār and Bhopāl. He gives an account of Dhār in note XXVI, ibid., pp. IoI-IO2.

${ }^{41}$ Kincaid, "Rambles among Ruins in Central India", Indian Antiquary I7 (I888), pp. 348-352. The folkmemory of Bhoja is also documented by Alexander Cunningham, The Bhilsa Topes (London, I 854), p. 327.

${ }^{42}$ See History of Mandu, (ed.) Kincaid, p. I02.

${ }^{43} \mathrm{~J}$. Guiaud, The Ruins of Mandoo, the Ancient Mahommedan Capital of Malwah in Central India. From the Original Sketches of Captain Claudius Harris ... with Descriptive and Historical Notices, and an Appendix (London, I 860): preface (non pagination).

${ }^{44}$ C. E. Luard, Western States (Mālwā). Gazetteer, 2 parts. The Central India State Gazetteer Series, vol. 5 (Bombay, I908): part A, p. 40 I (hereinafter cited as Luard, Gazetteer).

${ }^{45}$ T. G. Mainkar, (ed.), Writings and Speeches of Dr. Bhau Daji (Bombay, I974), p. I40 where Dāji calculates Bhoja's date and mentions that he procured a manuscript of Dhanapāla's Tilakamañjarī. For Dāji collection, V. N. Mandlik and A. F. Moos, Catalogue of Manuscripts and Books belong to the Bhau Daji Memorial (Bombay, I882).

${ }^{46}$ Luard, Gazetteer, p. 401 .

${ }^{47}$ Georg, Bühler, Report on Sanskrit MSS. 1874-75 (Bombay, I875). S. R. Bhandarkar, Report of a Second Tour in Search of Sanskrit Manuscripts made in Rajputana and Central India in 1904-05 and 1905-06 (Bombay, I907): Bhandarkar (p. I) notes that Bühler's report of I 873-74 of his tour in Rajputana seems to have been lost but I find an account of the tour for that year by Bühler in Archibald Edward Gough, Papers relating to the Collection and Preservation of the Records of Ancient Sanskrit Literature in India (Calcutta, I 878), pp. I I 5-I 20. 
search. Besides the great library at Saidhpur Pattan, Gujarat, there are the royal and private libraries of Kasmir, Jammu, Jaypur, Udaypur, Ujjain, and Dhar, which, if explored, no doubt will yield the solutions of many problems of Sanskrit philology". ${ }^{48}$ This suggests that Bühler never reached Dhār in his quest for manuscripts.

Although Bühler cannot be placed in Dhār, it is nonetheless clear that he had an interest in the Paramāra dynasty and that he was well aware of the importance of Dhār as a centre of literary activity. ${ }^{49}$ In the course of his research into the Pāiyalachhī and Navasāhasāinkacarita, Bühler prepared the first study of the Udaypur praśasti of Udayāditya. ${ }^{50}$ In his article on this inscription, Bühler devoted considerable space to Bhoja's learning and proficiency as a poet, citing several manuscripts that supported the assertion in the praśasti that Bhoja was a poet-king. ${ }^{51}$ With reference to his temple building activities, also recounted in the Udaypur inscription, Bühler states, "Regarding the extensive building operations which Bhoja undertook according to verse 20 , I am unable to bring forward any corroboration from other sources. But it is very probable that a prince, so fond of display as he was, adorned his capital and perhaps even foreign sacred places with architectural monuments". ${ }^{52}$ To put the matter another way and in a succinct form relevant to our theme, Bühler had before him evidence of Bhoja's interest in literature and architecture, and of Dhār as a centre of literary production, but he did not speculate about the king building a school for Sanskrit studies or a temple to Sarasvatī. This is all the more telling because Bühler actively engaged with traditional knowledge-holders in India and knew about Sanskrit schools. A particularly interesting account of his encounter with Pandits working in the time-honoured manner is found in his report of 1869 . This is worth giving is full because it provides a clear sense of how Sanskrit learning and Sanskrit schools operated in the middle decades of the nineteenth century. ${ }^{53}$

After receiving charge of the office of Inspector, I addressed a circular to the Deputies of Surat, Broach, Kaira, Ahmedabad, Káthtiáwar, Rewakantha and Khandesh, requesting them to name the chief towns where Sanskrit manuscripts are found, and to furnish me with lists of the person possessing Sanskrit libraries ... On my tour, I visited a number of towns where Sanskrit learning is cultivated, amongst which I may mention Ahmedabad, Dholka, Limdi, Rájkoț, Gondal, Junágaḍh, Pálitáná, Bhaunagár, Nariad, Cambay, Broach, and Balsár. In all these places I had interviews with the Native scholars and possessors of libraries, and I explained to them the intentions of Government, and the purposes for which the present search for Sanskrit manuscripts is instituted. I mostly met with a very friendly reception on the part of the Bráhmans and Śástrís. They came willingly to talk with me, to show me the lists of their books, and to bring those which I wanted to inspect. At Balsár I held a regular sabbhá, or assembly of the learned, for

\footnotetext{
${ }^{48}$ Bühler in Gough, Papers relating to the Collection and Preservation of the Records of Ancient Sanskrit Literature, p. I2O.

${ }^{49}$ Bühler, "On a Prakrit Glossary entitled Pâiyallacchî", Indian Antiquary 2 (1873), p. I66 where Dhār is specifically mentioned as a "great centre of literary activity" under Bhoja.

${ }^{50}$ Bühler, "The Udepur Prasasti of the Kings of Malva," Epigraphica Indica I (I 892), pp. 222-238. The inscription, recording a Vaiṣnava foundation, was first found at Udaypur but what has not been noted before is that it came from the Varāha temple at Muratpur, about $5 \mathrm{~km}$. to the south, as noted by Ansari in this issue of the JRAS.

${ }^{51}$ Ibid., pp. $23 \mathrm{I}-232$.

${ }^{52}$ Ibid., p. 232 .

${ }^{53}$ Bühler in Gough, Papers relating to the Collection and Preservation of the Records of Ancient Sanskrit Literature, pp. 49-5I.
} 
the purpose of learned discussions. It was well attended. I examined first the pupils of the various Śástrís, and next proposed a few questions to the teachers, which they discussed in their peculiar manner, one upholding the Púrvapaksha, the first proposition, and the other its opposite, the Uttarapaksha. Finally I addressed them on the object pursued by Europeans in studying Sanskrit; the intentions of Government in regard to the cultivation of that language; the purposes for which Sanskrit books are collected, \& c. All these topics appear to have great interest for them, as they listened eagerly, and frequently asked question demanding fuller explanations. The ceremony was concluded by the recitation of improvised poetry, and the orthodox distribution of pán, supári and of dakshiná. In Junágaḍh, also, the whole posse of Śástrís was assembled at the examination of the Sanskrit School, and submitted to a rigorous examination in Sanskrit grammar; and I afterwards received a curious proof how deeply the Pundits had been impressed by seeing a foreigner able to converse in their sacred language and acquainted with their Śástras. On the last evening of my stay in Junágaḍh, a deputation came to me with an address, which assured me of their friendliness, and requested me to answer some questions, among the following were the most curious:

(I) Whether in Europe, especially in Germany, the learned lived according to the Bráhmanical law.

(2) Whether they performed sacrifices, as a European had done in Poona (Dr. Haug). ${ }^{54}$

(3) Whether I preferred sacrifices, or the study of the Vedánta, as the road to salvation.

(4) How, supposing that I was descended, as I had told them, from the Aryan stock, I could consider myself entitled (adhikrta) to study the Vedas and Śástras without having been initiated.

Though I hereupon disclaimed all belief in the Vedas and Śástras, I succeeded in satisfying them that I had no sinister intentions against their creed; and one of them volunteered to teach me the correct way of reading the Śatapathabráhmana from Professor Weber's edition.

If we cannot place Bühler in Dhār, the same is not true of his protégé Dr Alois Anton Führer (I 853-I930). He visited central India in I 892-93 and published an account of his tour in the Annual Progress Report of the Archaeological Survey Circle, North-western Provinces and Oudh. ${ }^{55}$ Reading Führer's report as a whole, one is struck by the ambitiousness of his itinerary and the lightning speed with which he travelled across Rājasthān and Mālwa. The hurried nature of the tour shows in Führer's frequent mistakes and his basically meaningless comments on architecture. These consist of aesthetic disquisitions with a top-dressing of disparaging remarks about the influence of Islam, a stock-in-trade of British historical interpretation designed to undermine the Islamic rulers of India and highlight the benefit of colonial rule. About the temples at Mount Ābu he thus noted: "These two temples are perfect gems of Indian art workmanship and monuments of the architectural, plastic, and decorative arts based on sound principles of design and imbued with the hereditary skill of the artists, and preserved to us from the ravages of time and iconoclastic tendencies of the Musalmân rulers of India". At Ajmer he admired the design of the mosque, but was compelled to say that it

\footnotetext{
${ }^{54}$ Martin Haug (I 827-76); German Indologist in India from I859 to I 866, who became Professor of Sanskrit and Comparative Philology at the University of Munich in I 868.

${ }^{55}$ A. Führer, "Progress Report of the Epigraphical Section for the Working Season of I892-93" in Annual Progress Report of the Archaeological Survey Circle, North-western Provinces and Oudh, for the year ending 3oth June, 1893 (Rourkee, I 893), pp. 8-29.
} 
was built "of the spoils of many Hindû temples which were thrown down by the bigotry of these conquerors". 56

We are under no obligation to take any of this seriously. What is a matter of concern is the fact that Führer was a persuasive and charismatic individual responsible for a series of audacious scholarly deceptions. Those from the first part of his career have been explored by Professor Andrew Huxley in a previous volume of this journal. ${ }^{57}$ Like many of his ilk, Führer seems to have combined an impressive personality with enough Indological knowledge to appear convincing, at least to those who did not know better or who did not take the time to check details. Of course the method of all con-artists, academic or otherwise, is to hoover-up other people's ideas, move quickly and create such a flurry of activity that details cannot be checked. Eventually, however, Führer was investigated and forced to resign from his position in the Archaeological Survey of India. That was in I898. Vincent Smith conducted the investigation and uncovered a breath-taking degree of bad scholarship and bad archaeological practice. Smith's report is essential reading for anyone interested in the Indological and colonial history of north India. Not previously published, the report is given here in an appendix.

This background helps us assess Führer's account of Dhār. Thus Smith's report, which tells us that Führer openly admitted that "he was not in the habit of keeping a journal of his tours or of writing up notes of his observations from day to day", helps explain how Führer could have said that the tomb of Shaykh Changāl "... is simply the transformation of a Jaina temple of the I2th century". ${ }^{58}$ Based on this, he concluded: "This mode of adapting Hindû temples to their own service has been practiced by the Musalmâns at Mându, Dhâr, Jaunpur, Zafarâbâd and many other places". There is, in fact, no trace of reused material in the fabric of the Dargāh or in the small mosque beside it, so either Führer never went there or is mixing up his memories. After all, he did not make field notes. Although inherently flawed, Führer's account is important because it points to a pattern of misrepresentation that culminates in the work of men like P. N. Oak. This writer has variously asserted that the Taj Mahal in Agra is a Rajput palace, a Hindu palace, a temple-palace and a temple. ${ }^{59}$ While scholars are apt to find these claims mildly amusing, the expression of such notions has influenced the destiny of several contested sites. Side-stepping the famous examples, I would point to a late Mughal mosque at Gwalior that was quietly turned into a temple sometime before $1980 .{ }^{60}$ Similar pressures surround the mosque of Kamāl al-Dīn at Dhār, as noted at the start of this essay. It is therefore significant that Führer remarked: "The dargâh of Maulânâ Kamâl-ud-dîn, built during the reign of Mahmûd Shâh Khiljî I., in A.H. 86I, has a spacious

${ }^{56}$ Ibid., p. 9 and p. I4.

${ }^{57}$ Andrew Huxley, “Dr Führer's Wanderjahre: The Early Career of a Victorian Archaeologist," JRAS 20 (2010), pp. $489-502$.

${ }^{58}$ Führer, "Progress Report", p. 22. The inscription at the tomb is discussed by Babagolzadeh in this issue of the JRAS.

${ }^{59}$ The trajectory of the 'thinking' is shown by the evolving title: P. N. Oak, Taj Mahal was a Rajput Palace (Delhi, I965); ibidem, Taj Mahal is a Hindu Temple (Bombay, I968), ibidem., The Taj Mahal is a Temple Palace (New Delhi, I974), ibidem., The Taj Mahal is Tejo Mahalaya: a Shiva Temple (New Delhi, I978), ibidem., Taj Mahal, the True Story: the Tale of a Temple Vandalized (Houston, Tex., I989).

${ }^{60}$ Alexander Cunningham, "Gwaliar, or Gwalior," Archaeological Survey of India Report 2 (1 $862-65$ ), p. 335. The mosque was built on the site of the temple of Gwālipa according to an inscription of I664; Willis, Inscriptions of Gopakșetra (London, I996), p. 95. 
quadrangle with a colonnade of very fine Jaina pillars on each side within the square, and some are very elaborately sculpted in a similar style as those in the Dailwârâ temples at Abû. The floor is formed of black stone slabs from which Sanskrit inscriptions of the $12^{\text {th }}$ century have been effaced. The mihrâbs and mimbar of the masjid proper are very handsome. On two of the columns supporting the central dome of the masjid are inscribed a couple of grammatical sûtras, which show that they were probably part of a scholastic building". ${ }^{61}$ This is the first published suggestion that the mosque, or the fragments built into it, marked the location of some kind of school. Of course Führer had no evidence for the proposition and he probably developed the idea from Bühler's Sanskrit researches noted above. All the ingredients are there in Bühler's writing and Führer consistently drew on Bühler's work, often copying out Bühler's words verbatim, as Huxley's meticulous research has shown. ${ }^{62}$

After Führer was dismissed in I898, his work was not cited as a source of reliable information. ${ }^{63}$ There is circumstantial evidence, however, that Führer's observations were picked up by the local officials with whom he interacted in the course of his tour and that the origin of 'Bhoja's school' and all the problems that have attended this identification can be placed at Führer's doorstep. But with this we get ahead of ourselves.

Returning to the sequence of events in proper chronological order, we know that there was a significant increase in research activity at Dhār in preparation for the visit of Lord Curzon in November, 1902. Captain Ernest Barnes, I.C.S., who served as the political agent at Dhār from I900 to I904, established a small archaeological department in September, I902 and placed the Superintendent of State Education, Mr. K. K. Lele, in charge. ${ }^{64}$ Just prior, Barnes collected available information on Dhār and Mạnḍu and communicated his findings to the Royal Asiatic Society, Bombay Branch, in June, I902. ${ }^{65}$

Barnes's report contains a wealth of information and includes some important details about the archaeological investigations taking place at the mosque next to Kamāl al-Dīn's tomb. Most importantly, Barnes's report shows that by the time he was writing, Lele had found two serpentine inscriptions giving the alphabet and grammatical rules of the Sanskrit language. ${ }^{66}$ These were understood by Barnes as "confirming the local tradition" that the mosque was "known among the Hindoo population as 'Raja Bhoja ka Madrassa', i.e. Raja Bhoja's school". ${ }^{67}$ Barnes does not tell us how he came to know this "local tradition", but we can conclude, quite safely I think, that it was given to him by his informants, i.e. Lele and his

${ }^{61}$ Führer, "Progress Report", p. 2 I.

${ }^{62}$ Huxley, "Dr Führer's Wanderjahre", p. 495.

${ }^{63}$ J. M. Campbell, “Art. XI. - Mándu," JRAS Bombay Branch I9 (I895), pp. I 54-20 I does not refer to Führer or to Dhār, so is not directly relevant. However I feel compelled to note here that Henry Cousens, "The Iron Pillar at Dhār", Archaeological Survey of India, Annual Report, 1902-03 (Calcutta, I904), p. 2 I I states that Campbell has mistakenly described the position of one of the iron pillar fragments and that "it is curious how both Sir James Campbell and Dr Führer make the same mistake, unless the one simply copied his account from the other". This is wrong. Campbell did not describe a piece of the iron pillar as standing outside the mosque at Māndū. Cousen's error is perpetuated in Balasubramaniam, "A New Study", p. I 2 I whose historiography is muddled. Kincaid's note in History of Mandu, p. IO2 (commenting on p. I6) shows that the position of fragments in I844 and I879 were: (I) the Lāt mosque, (2) "some pieces in the Dhar fort" and (3) "the block of iron opposite Hindoli mahal at Mandu". Führer has the piece at Māṇụu in front of the mosque in I893, but Campbell reports no piece there in I895.

${ }^{64}$ Luard, Gazetteer, p. 40I. This was Io years after Führer's visit, so it is possible that Führer and Lele met, more on which below.

${ }^{65}$ Barnes, "Dhar and Mandu," pp. 339-390. The date of the communication is given at the head of the article.

${ }^{66}$ Ibid., p. 350.

${ }^{67}$ Ibid., p. 350. 
assistant Babaji Nalchekar, both of whom are thanked by Barnes in his opening remarks. ${ }^{6}$ In other words, the "local tradition" of the "Hindoo population" is nothing more than what was reported to Barnes by Lele. How Lele formed his views, based on Führer's report, is something to which we will return shortly.

Concluding his account of the mosque, Barnes wrote: "Finally, a recent close inspection has brought to light the fact that the reverse side of two of the great black stone slabs which form the lining of the 'Mehrab' are covered with similar inscriptions, which happily by their position have escaped destruction, but which owing to that same position, it has only been possible up to the present to take fragmental impressions. These impressions seem to show that the inscriptions are a dramatic composition probably on an historical subject, written in the reign of a successor of Bhoja". ${ }^{69}$ The state of understanding in the middle of 1902 is therefore clear: the mosque was being called 'Raja Bhoja's Madrassa' thanks to the two serpentine inscriptions found at the site by Lele but it was not yet known as the Bhojśâlā and it was not yet associated with the goddess Sarasvatî.

Five months after Barnes completed his article, Lord Curzon came to Dhār. This visit was part of a wider campaign, which Curzon was leading, to modernise the government of India, not least the Archaeological Survey. ${ }^{70}$ During Curzon's visit, Lele reports that the inscribed slabs he had discovered "were seen by His Excellency Lord Curzon, Viceroy and Governor-General of India while yet in the wall on the $2^{\text {nd }}$ November I902. By his H. E.'s advice they were taken out and have since attracted much attention and interest". We owe the preservation of this information to S. K. Dikshit who decided to print Lele's account in his 1968 edition of the inscription. ${ }^{71}$ Lele's report is titled: Summary of the Dramatic Inscription found at the Bhoja Shala (Kamal Maula Mosque), Dhar, C. I., in November 1903. This is of historical importance because it is the first recorded use of the word 'Bhojsâlà'. Coincidentally, the Summary also shows that Lele was a very competent Sanskrit scholar who took just a few weeks to read the inscription and grasp its purport and importance. It seems likely that he was trained in the kind of traditional Sanskrit school described by Bühler.

Lele circulated his report widely. This is shown, firstly, by the account of it given by R. Pischel in the Annual Report of the Archaeological Survey of India for $1903-04 .{ }^{72}$ Pischel was concerned with the Prakrit inscriptions and tells us that he received estampages from Professor E. Hultzsch who had them from John Marshall, the Director-General of

${ }^{68}$ Ibid., p. 339

${ }^{69}$ Ibid., pp. 35I-352. Lele reports that the slab with the dramatic text was "attached to the northern wall of the principal Mehrab with the writing turned inside”, see Dikshit, Pārijātamañjarī, p. xviii. The credit for the discovery must go to Lele. I should add here that the slabs, which have the usual horizontal format of Indian inscriptions and are now displayed on the back wall of the mosque inside the entrance, were turned on end when they were re-set in the milurab (thus with the writing on its side). I mention this only to forestall misguided suggestions that that mihrāb is some kind of temple niche or garbhagrha.

${ }^{70}$ See John Marshall's introduction to the Annual Report, Archaeological Survey of India, 1903-04 (Calcutta, I906), pp. I-2. The immediate effect of Curzon's vist on the conservation of monuments at Dhār and Māṇụu are recorded in Government of India, Proceedings of the Department of Revenue and Agriculture for July, 1903. Archaeology and Epigraphy, pp. 347-360 (India Office Proceedings P/660o).

${ }^{71}$ Dikshit, Pārijātamañjarī, p. xviii. Lele's report is dated 30 December I903. Dikshit had close relations with Lele's nephew and reveals (ibid., p. xiv) that he was the son of K. N. Dikshit, the Director General of the Archaeological Survey of India. The elder Dikshit's role in our story is taken up below.

${ }^{72}$ R. Pischel, "Inscriptions from Dhār", Archaeological Survey of India, Annual Report, 1903-04 (Calcutta, I906), pp. $238-240$. 
the Archaeological Survey. For our concerns, the key point is that Pischel accepted Lele's Summary at face value and innocently refers to the "discovery of the two long inscriptions and several fragments found in the Bhojaśâlā at Dhār". 73

Lele also sent his Summary to Hultzsch. This excited Hultzch's interest and, through various intermediaries, he received inked impressions and published the full text in the I905-06 volume of Epigraphia Indica. ${ }^{74}$ As it turns out, the ink impressions came from Henry Cousens who was also studying the antiquities of Dhār at the time. ${ }^{75}$ Cousens was concerned with the iron pillar and published his detailed study in the first volume of the Archaeological Survey of India Report for 1902-03. ${ }^{76}$ In his attempt to locate the surviving parts of this pillar and the history of their placement and movement, Cousens made enquires through Captain Barnes. In reply Lele wrote: “As soon as your letter came, I drove to the Agency House and made a search for the bell-capital near the Havaldar's house. Nothing like it was found there or anywhere else. But on further enquiries I found, near the bāghbān's house, a flat octagonal slab of ordinary black-stone, which old people say rested upon the lät while it was standing in the Agency garden ... When Dr. Führer visited Dhar this slab with its support might have appear to him bell-shaped."77

This statement is critical because it demonstrates a link between Lele and Führer. Whether Lele met Führer personally or knew him only through his I 893 report is probably something we shall never know for sure. Vincent Smith examined Führer papers in I 898 and noted that the lists of inscriptions and antiquities he found were not Führer's own work, but "prepared by local officials". ${ }^{78}$ Whether this shows that Führer met with Lele and took a list from him is uncertain, but it at least shows how Führer was able to give the correct dates and details for the Dhār inscriptions he mentions in his report. However that may be, the text of Lele's letter printed by Cousens leaves no doubt that Lele knew what Führer had said about Dhār and that he had a degree of respect for it. What this means is that Lele would have been aware of Führer's general understanding of Indian architecture, i.e. that that pre-Islamic temples were “... perfect gems of Indian art workmanship", which in some case were "... preserved to us from the ravages of time and iconoclastic tendencies of the Musalmân rulers of India”, and that " ... many Hindû temples ... were thrown down by the bigotry of these conquerors" but, nonetheless, Islamic rulers sometimes recycled older buildings to their needs, “... a mode of adapting Hindû temples to their own service ... practiced by the Musalmâns at Mându, Dhâr, Jaunpur, Zafarâbâd and many other places". ${ }^{79}$ Führer was not, of course, the inventor of this style of interpretation. It was Führer, however, who introduced these themes to Dhār and it was Lele who developed them in the local setting. ${ }^{80}$

\footnotetext{
${ }^{73}$ Ibid., p. 238.

${ }^{74}$ E. Hultzsch, "Dhar Prasasti of Arjunavarman: Parijatamanjari-Natika by Mandana", Epigraphia Indica 8 (1905-06): 96-I22. A translation had to wait until I968, see Dikshit, Pārijātamañjarí.

${ }^{75}$ Hultzsch, "Dhar Prasasti", p. 96 and Dikshit, Pārijätamañjarī, p. v.

${ }^{76}$ Cousens, "Iron Pillar at Dhār", pp. $205^{-2} \mathrm{I} 2$.

77 Ibid., p. 2 Io, n. I. It is not clear if Lele wrote to Barnes or directly to Cousens.

${ }^{78}$ See appendix for Smith's report. From the report we find Führer had in his papers a list prepared by William Kincaid. Kincaid had returned to Europe in I 886 and retired in I889, so it appears Führer was able to get hold of extant lists during his tour of $\mathrm{I} 892-93$.

${ }^{79}$ Führer, from his report cited above.

${ }^{80}$ The wider context is explored in Finbarr B. Flood, Objects of Translation: Material Culture and Medieval "Hindu-Muslim" Encounter (Princeton, 2009), esp. Chapter 5 without, however, reference to Dhār.
} 
The basic conundrum for Lele was that if the mosque at Kamāl al-Dīn was going to be explained away as a re-used Hindu building, then some sort of Sanskrit basis had to be found for 'Bhoja's school', the designation 'Rājā Bhoja kā Madrassa' being too manifestly Urdu to serve his purpose. Lele addressed the problem by inventing the term 'Bhojśâlā'. While this was a clever bit of Sanskritisation, it had no basis in common parlance or the architectural types known from ślpa-texts. A dharmśâlā was and is a well-known place of refuge for pilgrims, and there are various functional buildings called śâlā, such as those used by washer men $\left(\right.$ dhobisisalā) ${ }^{81}$ But there is no such thing as a Sanskrit śâla (that would be vidyālaya, vidyāâțha or jūānapițha) and no śălā named after a king. Lele coined the term to provide the descriptive terminology he needed for the pillared colonnades of the mosque and so advance the idea that the building was indeed an old structure put to new use by the Muslims.

Although Lele busied himself with promulgating the idea that the mosque was the Bhojśâlā, and had some success in this as we have seen, the proposal did not meet with universal acceptance. In Luard's landmark Gazetteer of 1908, the buildings of Dhār are described and 'Bhoja's school' duly noted. Because the statements that appeared in this publication were well-researched and represented an official government record, they have been repeated in more recent gazetteers and have enjoyed popular currency. This happened even though Luard openly stated that the name 'Rājā Bhoja's School' was "a misnomer" ${ }^{82}$ Why Luard did not simply suppress the misnomer may be explained by the fact that his Gazetteer was meant to be an up-to-date account of realities on the ground, not a definite historical assessment.

Luard's scepticism was well grounded. No text mentioning the Bhojs̄âlā was known in Luard's time and no text or inscription has been found subsequently. This shows that the present 'tradition' about the Bhojśâlā has been created retroactively from the gazetteers. This conclusion is supported by the application of the sources at the hands of the historian K. M. Munshi. He asserted that: "Close to Sarasvatī-mandira was a large well, still known as 'Akkal-Kui' or the 'Well of Wisdom'" ${ }^{83}$ What Munshi omits to tell us is that he has lifted this information directly from the History of Mandu where it is recorded that the well took its name from the hundred Arabic books that fell accidentally into the well a long time ago, thus giving the name Akl ka kua. ${ }^{84}$ The Islamic source of the legend is proven by the fact that akl is an Arabic word pure and simple.

\section{Sarasvatī}

The comment of K. M. Munshi just cited brings us to the final part of the Bhojs̄âlā puzzle, namely the goddess Sarasvatī. As my readers may have noticed, there is no trace of this goddess in Lele's writing or that of his contemporaries. What brought Sarasvatī into the limelight was Tawney's translation of the Prabandhacintämani. This text, published in I90 I, includes several

\footnotetext{
${ }^{81}$ An inscription found in such a place mentioned in Trivedi, Inscriptions of the Paramaras, probably marking the site of a ruined temple given the proximity to water.

${ }^{82}$ Luard, Gazetteer, p. 498.

${ }^{83}$ K. M. Munshi, Glory that was Gūrjaradeśa: A.D. 500-1300 (Bombay, I955), p. 284.

${ }^{84}$ History of Mandu, note XXVI, p. IO2.
} 
episodes describing King Bhoja's visits to the temple of Sarasvatī at Dhār. Merutunga calls the temple the Sarasvatīkanthäbharana or Necklace of Sarasvatī, transposing on the building the name of two texts attributed to Bhoja that were known in western India at the time. ${ }^{85}$ So with Mertunga telling us that Bhoja visited the temple of Sarasvatī and with the inscription of Arjunavarman telling us that the Pärijātamañjari was performed in the temple of Sarasvatī, all that was missing from the picture was the statue of Sarasvatì herself. This gap was filled in I924. O. C. Gangoly and K. N. Dikshit discovered an inscribed sculpture in the British Museum and straightaway announced that it was Bhoja's Sarasvatī from Dhār. ${ }^{86}$ The sculpture is shown here in Fig. 4. Gangoly was a celebrated art historian and Dikshit the DirectorGeneral of the Archaeological Survey of India, so their discovery was universally accepted and had a significant impact. The British Museum sculpture was repeatedly identified as Bhoja's Sarasvatī in the years that followed, most notably by C. Sivaramamurti, one-time Director-General of the National Museum of India. ${ }^{87}$ Some writers, such as K. M. Munshi and V. Raghavan, have also asserted that the British Museum sculpture was from the mosque of Kamāl al-Dīn. ${ }^{88}$ This is not correct. Already in I943, C. B. Lele, who had access to the archival sources, reported that the sculpture had been found in the debris of the old city palace in I $875 .{ }^{89}$ The city palace was being rebuilt at that time and stands facing the central square of the town. The building is now used as a school.

The inscription on the British Museum sculpture is damaged, but clearly mentions King Bhoja and Vāgdevī, another name for Sarasvatī. The editio princeps was prepared by H. V. Trivedi and published in Corpus Inscriptionum Indicarum..$^{90}$ A re-examination of the inscription was undertaken by H. C. Bhayani, the well-known Sanskrit and Prakrit scholar. This was published in I98 I in an article co-authored with Kirit Mankodi. ${ }^{91}$ Their study showed that the inscription records the making of a sculpture of Ambikā after the creation of three Jinas and Vāgdevī. In other words, although Vāgdevī is indeed mentioned, the inscription's main purpose is to record an image of Ambikā, i.e., the sculpture on which the record is incised. That the sculpture is Ambikā is confirmed by the iconographic features,

\footnotetext{
${ }^{85}$ The two texts deal with grammar and poetics; for the title in western India see Ājada's commentary cited above in note 4. Sarasvatīkanțhābharaṇa with the commentary of Śr̄̄ Nārāyaṇadaṇ̣̂anātha, (ed.) K. Śāmbaśiva Śāstrī (Trivandrum, I935-), also see R. Birwé, "Nārāyaṇa Danḍanātha's Commentary on Rules III.2, pp. IO6-I2I of Bhoja's Sarasvatikanțhābharaṇa," Journal of the American Oriental Society 84 (I964), pp. I 50-I62. The poetic text was published most recently as Sarasvatīkanthäbharanam of King Bhoja, 3 vols., edited and translated by Sundari Siddhartha (Delhi, 2009). I am obliged to note that, contra Pollock, the Sarasvatīkanthābharanaprāsāda does not refer to the royal palace of King Bhoja; in the context set out by the Prabandhacintämani it means temple. S. Pollock, The Language of the Gods in the World of Men (Berkley, 2006), p. I80, referencing "Tilakamañjari, p. 5 and CII 7.2: 49 and n. 3 ”. This footnote simply re-cycles the incomplete and incorrect reference in Trivedi, Inscriptions of the Paramāras, 2, p. 49 .

${ }^{86}$ O. C. Gangoly and K. N. Dikshit, “An Image of Saraswati in the British Museum,” Rūpam I7 (January, I924), pp. I-2.

${ }^{87}$ C. Sivaramamurti, Indian Sculpture (New Delhi, I96I), p. I06.

${ }^{88}$ Munshi, Glory that was Gūrjaradeśa, p. 284; Raghavan, Bhoja's Śringaraprakāśa, front matter (no pagination). Reasoning like this, one might as well argue that the second slab from the mihrāb of the mosque with verses to Kūrma shows that the Bhojs̄âlā is Bhoja's Kūrma temple! The odes to the Tortoise incarnation are taken up in Devangana Desai, “Two Inscribed Kūrma Śatakas Attributed to King Bhojadeva”, Journal of the Asiatic Society of Mumbai 77-78 (2002-03), pp. 42-48.

${ }^{89}$ [C. B. Lele], Parmar Inscriptions in Dhar State, $875-1310$ AD (Dhar, [1944]): iii. C. B. Lele was the nephew of K. K. Lele.

${ }^{90}$ Trivedi, Inscriptions of the Paramāras, 2, p. 49.

${ }^{91}$ Kirit Mankodi, "A Paramāra Sculpture in the British Museum: Vāgdevī or Yakshī Ambikā?”, Sambodhi 9 (I980-8I), pp. 96-IO3.
} 


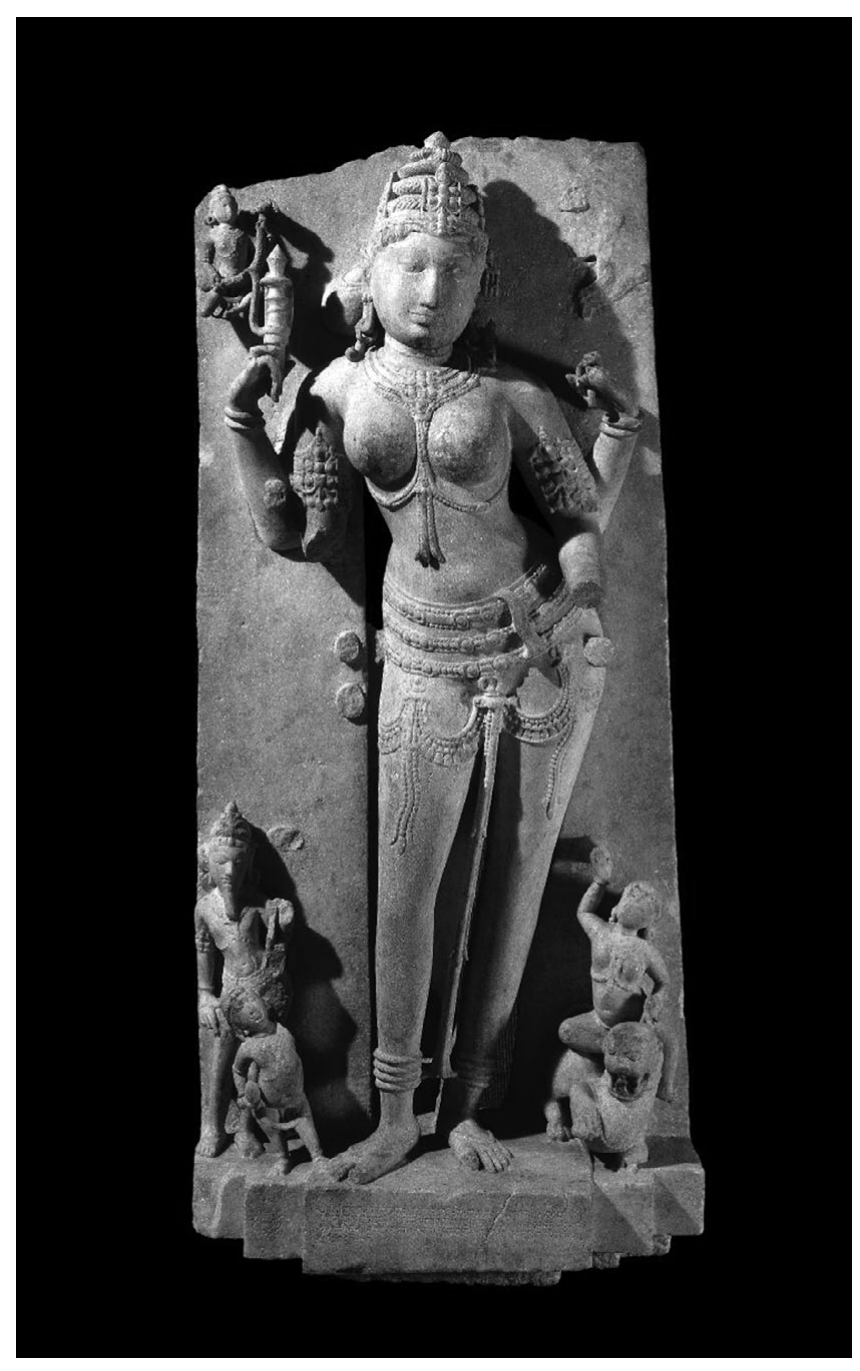

Fig. 4. Standing figure of the Jain goddess Ambikā. Courtesy of the British Museum.

notably the lion and elephant goad. ${ }^{92}$ The composition also leaves space for a mango cluster in one of the missing hands, a frequent attribute of Ambikā. This is alluded to in the inscription which describes the goddess as 'ever abundant in fruit'.

The epigraphic features of the record have been noted by H. V. Trivedi in his edition of the text to which the interested reader is referred. The main advance offered here is the identification of the grammatical subject of the text. This appears in line 2 where the reading vararucih is clear. The purport of the inscription is, therefore, that an individual named Vararuci made the image of Ambikā on which the text has been engraved.

\footnotetext{
${ }^{92}$ M. N. P. Tiwari, Ambikā in Jaina Art and Literature (New Delhi, I989).
} 


\section{$\operatorname{Text} t^{93}$}

(I) aum | srīmadbhojanāreṃdracaṃdranagarīvidyādharī [*dha]rmmadhīh yo - - U U - U [damaged portion] khalu sukhaprasthāpanā-

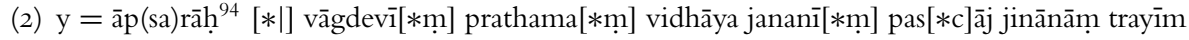
ambā $\left[* m\right.$ ] nityaphalādhikāṃ vararucih ${ }^{95}(\mathrm{~m})$ ūrttim subhā[ṃ] ni-

(3) rmmame [II] iti subhaṃ || sūtradhāra sahirasutamaṇathaleṇa ghaṭitạ̣ || vi[jñā]nika sivadevena likhitam iti \|

(4) samvat IO0 9I $[\| *]$

\section{Translation}

Aum. Vararuci, King Bhoja's religious superintendent of the Candranagarī and Vidyādharī [branches of the Jain religion], an apsaras (as it were) for the easy removal [of ignorance? (damaged portion)], that Vararuci, having first fashioned Vāgdevī the mother (and) afterwards a triad of Jinas, made this beautiful image of Ambā, ever abundant in fruit. Blessings! It was executed by Maṇathala, son of the sütradhära Sahira. It was written by Śivadeva the proficient. Year I09I.

A number of historical problems which are raised by the record cannot be addressed here in detail, notably the identification of the Vararuci named as the sculpture's patron. There are a number of people named Vararuci in the literary history of India and by the eleventh century it seems likely that Vararuci was not a personal name but a courtly pseudonym for a high-placed Paramāra official with literary aspirations. ${ }^{96}$ Whoever he may have been, the text of the inscription notes that Vararuci made an image of Vāgdevī and three Jinas before he commissioned the image of Ambikā. This indicates that Vararuci was a follower of Jainism and, by extension, that the Vāgdevī at Dhār was dedicated to the Jain form of the goddess. This is confirmed by the Prabandhacintamani. In this text there is a story that Dhanapala, the celebrated Jain savant and author, showed King Bhoja some eulogistic tablets in the Sarasvati 1 temple engraved with his poem to the first Jina. ${ }^{97}$ This text survives as the Rsabhapañcaśikāa ${ }^{98}$ Because an inscribed poem to the Jina would only appear in a temple sacred to Jainism, Merutunga's account shows that the Vāgdevī at Dhār was indeed the Jain form of the goddess, just as the British Museum inscription attests.

The Jain affiliation of the inscription begins to explain the first half of the verse, although this remains problematic given the damaged surface and lacuna in the text. The word dharmadhit agrees with Vararuci and means "he whose mind is on the dharma" or, more simply, "religious". Here however, the word would appear to refer to an office or role under King Bhoja. The dharma on which Vararuci was to focus is given in the long compound: srìmad-bhoja-naremdra-camdra-nagari-vidyādhari-dharmadhïh. This does not refer, as previous

\footnotetext{
${ }^{93}$ The metre is Śāradūlavikrīdita.

${ }^{94}$ Construe as sukhaprasthäpanāy $=\bar{a} p s a r a ̄ h$. The syllables immediately before are damaged and not legible but their number and length is indicated by the metre.

${ }^{95}$ The visarga is clearly visible, excusable at the yati, but anyway read: vararucir.

${ }^{96}$ I have presented some preliminary thoughts about the identification of Vararuci as Dhanapāla in my "New Discoveries from Old Finds: A Jain Sculpture in the British Museum”, Centre of Jain Studies Newsletter 6 (20 I I), pp. 27-29.

${ }^{97}$ Tawney, Prabandhacintāmani, p. 57.

${ }^{98}$ Warder, Indian Kāvya Literature, 5: \$42 Iо.
} 
editors have supposed, to a Vidyādharī or 'holder of knowledge' in the city of the 'moonking Bhoja' (an especially infelicitous gloss). Rather, the words refer to the Candranagari and Vidyādharī branches or śăkhā of the Jain community. Jainism is organised into an hierarchical series of groups known as gana, kula and śäkha. The gana - termed gaccha in later times was an assembly following the same rules of conduct (samācärì). The gana was made up of preceptor-disciples lineages known as kula, roughly speaking 'spiritual 'families'. Monks following a specific teacher were classified into śăkhās or branches. Members of these branches were often of the same kula. The Candranagarī and Vidyādharī branches are ancient and known from inscriptions and the Kalpasuttra. ${ }^{99}$ The fact that these śäkhäs were part of the Śvetāmbara church appears to show why they needed oversight: the Śvetāmbaras had close links to western India and the court of the Câlukyas, a dynasty in direct conflict with the Paramāras. Śvetāmbaras, therefore, had to be watched lest they be tempted to collude with the enemy.

The current location of the Sarasvatī from Dhār remains an interesting mystery seeing that it is not located in the British Museum. There are famous and ancient Sarasvatī temples at several locations in India, notably Maihar in eastern Madhya Pradesh and in Kashmir. ${ }^{100}$ The site in Kashmir is known as Sāradā pịtha. ${ }^{101}$ Envoys from Gujarāt visited this temple in the twelfth century to collect texts so the western Indian polymath Hemacandra could compose his comprehensive grammar, the Siddhahema. ${ }^{102}$ A more aggressive approach was taken by the Solanikī and Vāghelā rulers toward Dhār. They sacked the city repeatedly in the dying days of the Paramāra regime, removing the libraries to their own cities where Paramāra texts were copied, studied and preserved. ${ }^{103}$ The inscription of Vīsaladeva from Kodinar dated I27I records the creation of a pleasure garden (ketana) and college (sadas) sacred to Sarasvatī. ${ }^{104}$ This suggests that in addition to removing books, the western Indian kings also took away the sacred image of Sarasvatī, installing her in a new temple in Saurāstra, not far from Somnāth. The practice of moving images is well-testified. Aside from the examples documented by Richard Davis, attention may be drawn to Jinaprabhasūri (d. I333) who states that an image of Candraprabha came to Somnāth from Valabhi along with figures of Ambā and Ksẹtrapāla. ${ }^{105}$ We should not, therefore, entertain the idea that Sarasvatī remains hidden somewhere in Dhār never mind spirited away to London in colonial times.

\section{Indology}

Those who practice bad science certainly undermine science in society, but they do not invalidate the scientific method as such. Similarly, Indology badly done and contaminated

${ }^{99}$ S. B. Deo, History of Jaina Monachism from Inscriptions and Literature (Poona, I956), pp. 36I-364. Jain, Jaina Sects and Schools, p. 5I. I am grateful to Paul Dundas for suggesting that the inscription appears to refer to branches of the Jaina faith, personal communication, April, 2009.

${ }^{100}$ D. C. Sircar and V. S. Subrahmanyam, "Inscriptions from Maihar," Epigraphia Indica 35 (1963-64), pp. I7I-I 78 .

${ }^{101}$ D. C. Sircar, The Śäkta Pìthas (Delhi, I973), p. Is.

${ }^{102}$ According to the Prabhâvakacarita, a text dated I277-78; translation in Pollock, The Language of the Gods, p. 589 . Pollock, however, has given the wrong date for the work.

${ }^{103}$ As noted in Pollock, Language of the Gods, p. I 8 I.

${ }^{104}$ Gadre, Important Inscriptions, no. Io.

${ }^{105}$ Cited in U. P. Shah, Jaina Rūpa Mandana (New Delhi, I987), p. I42; Richard Davis, Lives of Indian Images (Delhi, I999). 
by the imperial project may be the source of the Bhojsāana imbroglio and the basis of an entirely false religious tradition, but that, however deserving of condemnation, does not destroy the validity of Indology as a discipline. In this essay I have attempted to show that Indology, i.e. the comprehensive examination of sources, has power to bring us closer to the historical realities of medieval India. The importance of retaining an ability to deal with these sources, generally dismissed as irrelevant in the modern academy, is nowhere clearer than on the threshold of the Bhojs̄alā. Claims and counter-claims about the place can only be measured against sources in Sanskrit, Prakrit, Persian, Arabic, Urdu and English. But if nobody can read these sources and evaluate them, then who can make any kind of valid assessment? To conclude I quote the words of the forward-looking Captain Barnes: "I would .. content myself with the hope that the present work, however imperfect, will serve to stimulate inquiry, and that in the future progress may not depend solely on the chance interest displayed by European officials, but that native gentlemen, many of whom are well-fitted to take up the work, will recognise that it is part of their duty to their country to endeavour to preserve from oblivion the records of the past". ${ }^{106}$ Sadly, the state of learning has declined after a period of initial promise and Barnes would be dismayed to know that the "native gentlemen' well-fitted to take up their duty to their country - men like D. C. Sircar, G. H. Yazdani, Z. A. Desai and V. V. Mirashi - have disappeared as a breed in India.

\section{Key works cited}

Ernest Barnes, “Art. XI. - Dhar and Mandu.” JRAS Bombay Branch 2I, I903. pp. 339-390.

Henry Cousens, "The Iron Pillar at Dhār" Archaeological Survey of India, Annual Report, 1902-03. (Calcutta, I904), pp. 205-2I2.

S. K. Dikshit, (ed.) Pārijātamañjarī alias Vijayaśrī by Rāja-Guru Madana alias Bāla-Sarasvatī. (Bhopal, I968).

Phyllis Granoff, "Sarasvatî’s Sons: Biographies of Poets in Medieval India." Asiatische Studien / Études Asiatiques 49.2, I995. pp. $35 \mathrm{I}-376$.

William Kincaid, (ed.) History of Mandu, The Capital of Malwa. By a Bombay Subaltern, $2^{\text {nd }}$ ed. (Bombay, I879).

C. B. Lele, Parmar Inscriptions in Dhar State (Dhar, 1944).

C. E. Luard, Western States (Mālwā). Gazetteer, 2 parts. The Central India State Gazetteer Series, vol. 5. (Bombay, I908).

Kirit Mankodi, "A Paramāra Sculpture in the British Museum: Vāgdevī or Yakshī Ambikāe” Sambodhi 9, I980-8I. pp. 96-103.

H. V. Trivedi, Inscriptions of the Paramāras, Chandellas and Kachchapapaghätas and two Minor Dynasties. Corpus Inscriptionum Indicarum, volume 7, 3 parts. (New Delhi,I979-9I).

\section{Appendix}

I am grateful to Mr. T. Phelps for drawing my attention to this document in the National Archives of India and for providing me with his photocopy of it. Aside from exposing Führer, this document is a useful indicator of how the British administration compiled archaeological information. It shows, moreover, Führer's connection with local officials in

\footnotetext{
${ }^{106}$ Barnes, "Dhar and Mandu”, p. 340.
} 
central India. I have not included Smith's extended comments in this report on the Nepal Terai and Kapilavastu because this is outside the scope of the present article and takes us to a separate set of problems that merit independent examination.

$* * * * *$

File no. I 3 of I 899, Serial no. 37, I 899, Archaeology and Epigraphy, Department of Revenue and Agriculture. Proceedings for April/99, no. I6, part B.

(OC-I I/95/Pr I (R II).

Subject: $\mathrm{D}^{\mathrm{r}}$ Führer's discoveries in the Nepal Tarai, Inspection of $\mathrm{D}^{\mathrm{r}}$ Führer's Office by V. A. Smith

Dated: Naini Tal, the ${ }^{8^{\text {th }}}$ October 1898 .

From: W. G. Wood, Esq, Under-Secy. to Govt., N.-W. P. and Oudh, P. W. D.,

To: The Secretary to the Government of India, Department of Revenue and Agriculture (Archaeology and Epigraphy)

Sir,

With reference to your letters, No. $2568-\mathrm{I} 3-\mathrm{I} 2$ of the $22^{\text {nd }}$ September I 898 , and No. 2650-I $8-8$ of the $29^{\text {th }}$ September I 898 , I am directed to forward for the information of the Government of India a printed copy of a report of an Inspection of the Office of Dr. A. Fuhrer, Archaeological Surveyor, by Mr. V. A. Smith, Chief Secretary to this Government. A list of the facsimiles of Inscriptions, I Io in number, found in Dr. Fuhrer's room is attached. A copy of the list, so far as it relates to Burmah, with all books and papers relating to that province will be sent to the Government of Burmah. In regard to the Neapul excavations there are drawings and photographs and Mr. V. A. Smith will write such a report as is possible with scanty materials available.

2. Mr. V. A. Smith suggests that a copy of the list enclosed should be sent to Dr. Hultzch, Government Epigraphist, Otacamund, in order that he may select for publication any of the unpublished documents which he may consider worth publishing. I am to ask if this suggestion meets with the approval of the Government of India.

3. The Lieutenant Governor proposes to direct Mr. E. W. Smith, Assistant Archaeological Surveyor to this Government to relieve Dr. A. Fuhrer of both the offices held by him, namely the offices of Archaeological Surveyor and Curator of the Lucknow Museum. Mr. E. W. Smith when assuming charge of the office of Archaeological Surveyor will be careful to take over all drawings, photographs and other documents which still remain in Dr. Fuhrer's custody. Many papers were taken possession of by the Chief Secretary and are now in the Secretariat. The appointment of Mr E. W. Smith as Curator is proposed as a temporary measure to allow time for the decision of permanent arrangements. Very special care will be taken that Dr. Fuhrer take with him nothing belonging either to the Museum or the Archaeological Department.

I have the honor [sic.] to be, Sir, You most obedient servant, [signed] W. H. Wood, Under Secretary.

Enclosure: A list of inscriptions I Io in number found in Dr. Fuhrer's room. Printed report with 5 spare copies. 
Report on the Inspection of the Office of the Assistant Archaeological Surveyor, NorthWest Provinces and Oudh, at Lucknow, on the $22^{\text {nd }}$ September I898, by the Hon'ble Mr. V. A. Smith, I.C.S., Officiating Chief Secretary to the Government of the North-West Provinces and Oudh.

In accordance with the orders of the Government of India, contained in Mr. Holderness' demi-official letter dated $5^{\text {th }}$ September 1898 , to the address of the Hon'ble Mr. Odling, and in the official letter No. 2006-6-2, dated the $28^{\text {th }}$ July I 898 , from the Under-Secretary to the Government of India, Revenue and Agricultural Department, to the Secretary to Government, North-Western Provinces and Oudh, Public Works Department, which orders were conveyed to me by endorsement No. 2174E., dated the $6^{\text {th }}$ September I 898, I visited the Lucknow Museum by appointment and examined the papers of Dr. Führer in that officer's presence.

I was instructed to verify the exact stage which the compilation and printing of each of the lists marginally noted has reached, and to ascertain when Dr. Führer expects to finish them.

[in the margin]

Abstract Tabular Lists of Antiquities.

(I) North-Western Provinces and Oudh.

(2) Panjáb.

(3) Burma.

(4) Rájputána and Central India.

Detailed Lists.

(5) Panjáb.

(6) Burma.

(7) Rájputána and Central India.

Report on Kapilavastu and the Nepal Tarái.

I also desired to arrange that all documents, proofs, photographs, and the like, of which he has possession in his official capacity, should be duly taken over from him before he resigns office.

2. The Government of India will probably be surprised to hear that Dr. Führer has never put pen to paper on any one of the lists in question. All the statements in his letters asserting that the lists were nearly ready, in the press, and so forth, are simply falsehoods. I put each case plainly to Dr. Führer, and he admitted the falsity of his statements. It would be tedious and useless to go through the long series of falsehoods in Dr. Führer's correspondence with various Governments about the lists which he was supposed to be printing. It will suffice to quote one passage of concentrated fiction from an official printed report of his (Annual progress Report of the Archaeological Survey Circle, North-Western provinces and Oudh, for the year ending $30^{\text {th }}$ June I894, paragraph 2I).

This passage is as follows: "Small tabular lists, for administrative purposes, of the architectural and archaeological remains and buildings in the North-Western Provinces and Oudh, Rájputána, and Central India, were prepared and sent to press: similar lists for the Panjáb and Burma are now approaching completion. These lists have been prepared on a uniform plan, in accordance with the orders of the Government of India, in the Revenue 
and Agricultural Department (Archaeology), with a view to the selection of those remains requiring to be preserved and to their being made over definitely and permanently to the Public Works Department for conservation and restoration. The proofs of the large volume The Monumental Antiquities and Inscriptions of Rájputána and Central India, similar to that published by me for the North-Western Provinces and Oudh, were being passed through the press, and its issue may be shortly expected. Similar volumes of the Panjáb and Burma are in a more or less advanced state of progress."

I read this passage to Fr. Führer and he was compelled to admit that every statement in it is absolutely false. The small tabular list for the North-Western Provinces and Oudh, Rájputána, and Central India were not "prepared and sent to press"; they do not exist. Nor are the similar lists for the Panjáb and Burma "approaching completion"; they were never begun. The small tabular lists can only be prepared after the detailed lists have been compiled. The only detailed list in existence is that for the North-Western Provinces and Oudh; but the tabular list even for those Provinces has not been touched.

The statement that the proofs of the large volume on the antiquities of Rájputána and Central India were being passed through the press is an audacious falsehood. The similar volumes for the Panjáb and Burma, which were said to be in a more or less advanced stage of progress, have never been begun.

These various works, or some of them, have from time to time been publicly advertised as being in the press. All such advertisements must now be withdrawn.

3. Dr. Führer does not seem to possess even rough drafts or notes. He says that he was not in the habit of keeping a journal of his tours or of writing up notes of his observations from day to day.

How he managed to produce the books which he has produced, including some very credible works, I cannot understand. He is a most unmethodical and unbusinesslike person.

What his motive was in writing such a series of palpable falsehoods I cannot tell. His only excuse is that more was thrust upon him than he could possibly do. It may be true that he was asked to do an unreasonably large number of heavy tasks; in fact, I have no doubt he was asked to do too much; but he could easily have pointed this out, and if he had honestly done so, no one would have blamed him. He preferred to adopt the extraordinary course of systematic lying.

4. I took possession of all the papers produced by Dr. Führer which relate to the lists required from him. These papers are as follows:

\section{Burma}

(I) An extract from the Journal, Royal Asiatic Society, about relics found at Rangoon.

(II) Printed List of Objects of Antiquarian Interest in British Burma (Rangoon, Superintendent of Government Printing, I 892).

(III) Note on a Tour in Burma in March and April, 1892, by F. O. Oertel (Rangoon, I 893).

(IV) Printed lists sent in by the Commissioners of the Northern Southern and Eastern Divisions.

Dr. Führer has never written a line, and says that he possesses no notes or materials except those which he had embodied in the progress report dealing with Burma (I 893-94). 


\section{Punjáb}

For the Punjáb Dr Führer has nothing to show, except Mr. Rodgers' printed Revised List of Objects of Archaeological Interest (Lahore, no date).

\section{Rájputána and Central India, including Bundelkhand}

(I) Rough pencil notes taken from Dr. Führer on $22^{\text {nd }}$ September I898 (Rájputána and Central India).

(II) Inscriptions of Bhopal (Dr. Burgess' forms).

(III) List of Objects of Antiquarian Interest in the Bhopal Agency, by Colonel W. Kincaid.

(IV) List of Ancient Inscriptions in the Bhopawar Agency.

(V) List of Objects of Antiquarian interest in the Bhopawar Agency.

(VI) List of Objects of Antiquarian interest in the Kotah State.

(VII) List of Objects of Antiquarian Interest in the Gwalior Districts within the West Malwa Agency.

(VIII) Inscriptions in Central India and Bundelkhand (received with letter No. - , dated $20^{\text {th }}$ May I 887 from - Indore residency to Dr. Burgess).

(IX) List of Objects of Antiquarian Interest in the Bundelkhand Agency.

(X) List of Objects of Antiquarian Interest in the Goona Agency.

(XI) List of Objects of Antiquarian Interest in the Gwalior District.

(XII) List of Inscriptions in Gurrha State.

(XIII) List of Inscriptions in Raghogarh State.

(XIV) List of Inscriptions in Parun State.

(XV) List of Inscriptions in Tonk State.

(XVI) List of Inscriptions in Bhadowra State.

(XVII) List of Inscriptions in Umri State.

(XVIII) List of Inscriptions in Dharnaodha State.

The pencil notes indicate that Dr. Führer had thought of beginning work on the lists for those provinces but the notes are of very slight value. The lists above enumerated were prepared by local officials.

[The report concludes with an account of the Nepal Terai and Kapilavastu excavations.]

MICHAEL WILLIS

British Museum 